\title{
Pythium Species Associated with Root Dysfunction of Creeping Bentgrass in Maryland
}

Yan Feng and Peter H. Dernoeden, Department of Natural Resource Sciences and Landscape Architecture, Uni-
versity of Maryland, College Park 20742

\begin{abstract}
Feng, Y., and Dernoeden, P. H. 1999. Pythium species associated with root dysfunction of creeping bentgrass in Maryland. Plant Dis. 83:516-520.

Putting green samples $(n=109)$ were inspected for the presence of Pythium oospores in roots of plants from golf courses $(n=39)$ in Maryland and adjacent states. Twenty-eight Pythium isolates were recovered from creeping bentgrass (Agrostis palustris) $(n=25)$ and annual bluegrass (Poа аппиа) $(n=3)$ plants. Most isolates associated with Pythium-induced root dysfunction were from greens less than 3 years of age and were obtained primarily between March and June, 1995 to 1997. Eight Pythium species (P. aristosporum, P. aphanidermatum, P. catenulatum, $P$. graminicola, $P$. torulosum, $P$. vanterpoolii, $P$. volutum, and $P$. ultimum var. ultimum) were isolated from creeping bentgrass and two species (P. graminicola and P. torulosum) were from annual bluegrass. All species, except $P$. catenulatum, were pathogenic to 'Crenshaw' creeping bentgrass seedlings in postemergence pathogenicity tests. P. aristosporum $(n=3)$ and P. aphanidermatum $(n=1)$ were highly aggressive at a low $\left(18^{\circ} \mathrm{C}\right)$ and a high temperature $\left(28^{\circ} \mathrm{C}\right) . P$. graminicola $(n=1)$ was low to moderately aggressive. P. torulosum $(n=12)$ was the most frequently isolated species, but most isolates were either nonpathogenic or caused very little disease. P. aristosporum $(n=3)$ and $P$. aphanidermatum $(n=1)$ were highly aggressive and were associated with rapid growth at 18 and $28^{\circ} \mathrm{C}$ on cornmeal agar. $P$. volutum $(n=1)$ was highly aggressive at $18^{\circ} \mathrm{C}$, but was one of slowest growing isolates. Infected roots were generally symptomless, and the number of oospores observed in roots was not always a good indicator of disease or of the aggressiveness of an isolate. Large numbers of oospores of low or even nonpathogenic species may cause dysfunction of creeping bentgrass roots.
\end{abstract}

Hodges and Coleman (7) described Pythium-induced root dysfunction of creeping bentgrass. The primary field symptom was turf death in patterns typical of Pythium blight, but Pythium species were isolated from roots instead of from above-ground portions of the plant. They isolated $P$. aristosporum and $P$. arrhenomanes, which were pathogenic to secondary roots of creeping bentgrass. Hodges and Coleman (7) observed that infected roots were white but occasionally had buff-colored lesions. $P y$ thium species also cause root and crown rot of creeping bentgrass $(1,6,12)$. Field symptoms include chlorosis and loss of vigor and density, followed by necrosis. Nelson and Craft (12) reported that $P$. graminicola, $P$. aphanidermatum, $P$. aristosporum, $P$. torulosum, and $P$. vanterpoolii were pathogenic to roots of creeping bentgrass seedlings. Based on recovery frequency and pathogenicity studies, it was concluded that $P$. graminicola was the principal spe-

Corresponding author: Peter H. Dernoeden

E-mail: pd9@umail.umd.edu

Accepted for publication 10 February 1999

Contribution of the Maryland Agricultural Experiment Station.

Publication no. D-1999-0322-01R

(C) 1999 The American Phytopathological Society cies associated with root rot in New York State (12). Abad et al. (1) reported that 29 of 33 Pythium species isolated from turfgrasses with symptoms of Pythium root and crown rot were pathogenic to primary roots of creeping bentgrass seedlings. Among these, $P$. arrhenomanes, $P$. aristosporum, $P$. aphanidermatum, $P$. graminicola, $P$. myriotylum, $P$. tardicrescens, $P$. vanterpoolii, and $P$. volutum were highly aggressive. However, 16 of the 29 species were only weakly pathogenic or nonpathogenic. Abad et al. (1) concluded that $P$. arrhenomanes was the most important pathogen causing root and crown rot of creeping bentgrass in North Carolina. Hsiang et al. (8) reported that $P$. graminicola, $P$. torulosum, and $P$. ultimum were pathogenic to creeping bentgrass and perennial ryegrass (Lolium perenne) in Ontario and Quebec.

Pythium species are common inhibitants of turfgrass roots, but the nature of $P y$ thium-induced root dysfunction is imperfectly understood and the disease is difficult to diagnose. Furthermore, the Pythium species associated with roots of creeping bentgrass grown on greens in Maryland is unknown. The primary objectives of this study were to (i) recover Pythium species associated with roots of creeping bentgrass suspected to have Pythium-induced root dysfunction; (ii) identify the isolated Pythium species; and (iii) assess postemergence pathogenicity of the isolates on creeping bentgrass seedlings. Secondary objectives included assessing the potential relationships among growth rate of the isolates and other cultural or environmental factors associated with the occurrence of Pythium-induced root dysfunction.

\section{MATERIALS AND METHODS}

Media and culture conditions. Two different media were used to isolate Pythium species: (i) $2 \%$ water agar (WA) amended with $100 \mu \mathrm{g}$ of rifampicin per ml (Sigma Chemical Co., St. Louis); and (ii) modified pimaricin, ampicillin, rifamycin, and pentachloronitrobenzene (PARP) medium (1). The second medium (PARP) was used beginning in 1997. The PARP medium contained $10 \mathrm{mg}$ of pimaricin (Sigma Chemical Co.); $250 \mathrm{mg}$ of ampicillin (Sigma Chemical Co.); $100 \mathrm{mg}$ of rifamycin (Rifamycin SV; Sigma Chemical Co.); $100 \mathrm{mg}$ of a $75 \%$ commercial, wettable powder formulation of pentachloronitrobenzene (Olin Corporation, Little Rock, AK); and $17 \mathrm{~g}$ of Difco cornmeal agar (CMA) (Difco Laboratories, Detroit) per liter of deionized water (9). Isolates of Pythium species were maintained on CMA. For long-term storage of Pythium species, a mycelium plug cut from a 3-day-old CMA culture was placed in a test tube containing sterile, deionized water and stored at $10^{\circ} \mathrm{C}(1)$.

Isolation of Pythium species from turfgrass roots. All isolates were obtained from golf course putting greens in Maryland and surrounding states between 1995 and 1997. All samples $(n=109)$ were submitted by golf course superintendents to the Maryland Turfgrass Research Laboratory for analysis. All samples were free of other primary pathogens. Furthermore, infected roots were generally white and often free of lesions, and plants were therefore suspected as having Pythium-induced root dysfunction rather than root rot. Samples were prepared by washing soil from the roots and crowns of 12 randomly selected plants with one or more yellow leaves or leaves exhibiting tip-dieback. Root systems were visually inspected for oospores, lesions, and discoloration. Cleaned stems and roots were boiled in $5 \%$ potassium hydroxide, stained with $3 \%$ trypan blue in lactophenol, and viewed microscopically at $400 \times$ for the presence of oospores. Sporangia were observed rarely in roots, and we relied on the presence or absence of oospores for diagnostic purposes. Sporangia, however, only were observed as described below. Samples 
were judged as being positive for Pythiuminduced root dysfunction if $\geq 8$ of 12 plants had some oospores embedded in the root system and at least 2 of 12 plants had more than 20 oospores associated with the root system.

Samples $(n=28)$ with roots containing Pythium oospores were chosen for study. Pythium species were isolated from fresh roots of the same samples as those previously screened (i.e., not boiled or stained) using two methods. The most common method involved placing 12 roots and about 12 annual bluegrass leaf pieces ( 0.5 to $1.0 \mathrm{~cm}$ long) into a petri dish containing sterile, deionized water. The annual bluegrass leaf sections were previously sterilized by boiling in water for $10 \mathrm{~min}$. Mycelium growing from infected roots directly infected leaves, and when sporangia were produced, leaves were infected by zoospores. Infected leaf tissue was then blotted dry with filter paper and placed on WA. Pythium species grew from leaves within 48 to $96 \mathrm{~h}$, and mycelium growing at the margin of the colony was transferred to CMA. The second isolation method involved cleaning and plating 12 randomly selected stems plus roots. Tissues were blotted dry with filter paper, placed directly on the surface of PARP media, and incubated at $25^{\circ} \mathrm{C}$. Within 2 to 7 days of incubation, plates were observed for the presence of coenocytic Pythium mycelia. Hyphal tips from one randomly selected colony were transferred to CMA and maintained as previously described. Hence, there was no opportunity to assess the potential of more than one species being present in a sample. If bacterial contamination occurred, isolates were purified by placing mycelium between the bottom of a petri dish and the overlaying WA. Mycelium growing through the top of the WA could then be aseptically transferred to CMA (12).

Identification of Pythium species. A grass leaf culture technique was used to induce asexual and sexual reproductive structures. Four to six $1-\mathrm{cm}^{2}$ CMA plugs from 3-day-old cultures were placed onto the base of a sterile petri dish. Petri dishes were then flooded with a shallow layer of sterile, deionized water to cover the plugs, and 10 to 12 previously boiled $(10 \mathrm{~min})$ annual bluegrass leaf pieces $(0.5$ to $1.0 \mathrm{~cm}$ long) were placed in contact with the agar plugs and incubated in the dark at $25 \pm 1{ }^{\circ} \mathrm{C}$ $(1,12)$. Most leaf sections floated, while some were submerged. Isolates failing to produce sexual structures (MD-P-6, MD-P16, MD-P-17, and MD-P-20) were checked for heterothallism by pairing two colonies of similar isolates at random. Agar plugs $\left(1 \mathrm{~cm}^{2}\right)$ of isolates were placed at opposite sides of a petri dish containing CMA and incubated at $25^{\circ} \mathrm{C}$ (14). None of the pairings, however, resulted in production of sexual structures. Morphologies for taxonomic purposes were compared and described by growing isolates on CMA at $25^{\circ} \mathrm{C}$ (14). Species identification was determined by using the taxonomic keys of Middleton (11) and van der Plaats-Niterink (14).

Postemergence pathogenicity tests. The procedure described by Abad et al. (1) was used to test for pathogenicity. Inoculum was produced by the grass leaf culture technique described above. Grass leaf culture plates were incubated in the dark at $25 \pm$ $1^{\circ} \mathrm{C}$ for 72 to $120 \mathrm{~h}$, after which time, leaves would contain large numbers of sporangia or oospores. A top-dressing mix containing $94 \%$ sand and $6 \%$ clay and having a $\mathrm{pH}$ of 5.2 was used as a growing medium. The sandy mix was sterilized by autoclaving it three times at $121^{\circ} \mathrm{C}$ for $1 \mathrm{~h}$ at $138 \mathrm{kPa}$ (20 psi). Twelve-well tissue culture plates (Corning Glass Works, Corning, NY) were used in the assay. Six wells of each plate were filled with $4.0 \mathrm{~g}$ of sterilized sand followed by adding about $1.2 \mathrm{ml}$ of sterile, deionized water to each well. Six wells were empty. Each sand-filled well was then seeded with about 200 surfacedisinfested creeping bentgrass seeds ('Crenshaw'). Seeds were surfaced-disinfested for $2 \mathrm{~min}$ in a $10 \% \mathrm{vol} / \mathrm{vol}$ Clorox $(5.25 \%$ sodium hypochlorite) solution. Seeds were covered with a thin layer of sand, and plate lids were replaced. Plates were put in a covered plastic humidity box and placed on a laboratory bench until seeds germinated. Seven-day-old seedlings were trimmed to about $1 \mathrm{~cm}$ in height and then inoculated by placing one piece of a Pythium-infested annual bluegrass leaf into the sand at the center of each well. A layer of sand was added to cover the inoculum, but not the seedlings. Sterile, deionized water was added to each well to bring soil to saturation. Lids were removed, and plates were placed in a covered plastic humidity box and incubated with continuous fluorescent light at either 18 or $28^{\circ} \mathrm{C}$. Disease incidence was rated as percentage of dead seedlings relative to the noninoculated control 7 days after inoculation (1). Pathogenicity or isolate aggressiveness was described as follows: nonpathogenic $=0$ mortality; low level aggressiveness $=1$ to $10 \%$ mortality; moderately aggressive $=11$ to $20 \%$ mortality; and highly aggressive $=\geq 21 \%$ mortality. Plates were arranged in a completely randomized design with three replicates per treatment within an incubator. Data were analyzed using the PROC TTEST in the SAS procedure, and significantly different means between 18 and $28^{\circ} \mathrm{C}$ were separated by the $t$ test $(P=0.05)$ (SAS Institute, Cary, NC).

Growth rate measurements. Twentythree Pythium isolates were evaluated for growth rate. A mycelial disk (5-mm diameter) was removed from the edge of a 3-dayold CMA colony and placed in the center of a petri dish $(100 \times 15 \mathrm{~mm})$ containing CMA. Three replicate plates for each isolate were randomized in separate, dark incubators at either 18 or $28^{\circ} \mathrm{C}$. Colony di- ameters were measured at 24 and $48 \mathrm{~h}$ using a ruler. The experiment was repeated by switching incubators, and data from both trials were combined for the analysis. The experiment was analyzed as a completely randomized block, split-plot design with two replications (i.e., growth chambers). The model for the experimental design was $\mathrm{Y}_{\mathrm{ijk}}=\mu+\mathrm{Y}_{\mathrm{k}}+\alpha_{\mathrm{i}}+\omega_{\mathrm{ki}}+\beta_{\mathrm{j}}+\alpha \beta_{\mathrm{ij}}+\varepsilon_{\mathrm{ijk}}$, in which $Y_{\mathrm{ijk}}=$ the observed value; $\mu=$ the grand mean; $Y_{k}=$ the incubator (block) effect; $\alpha_{i}=$ the temperature (main unit) effect; $\omega_{\mathrm{ki}}=$ the error for the block and temperature; $\beta_{\mathrm{j}}=$ the isolate (subunit) effect; $\alpha \beta_{\mathrm{ij}}=$ the interaction effect of temperature and isolate; and $\varepsilon_{\mathrm{ijk}}=$ the random error (13). Growth rate data were analyzed using the PROC MIXED procedure in SAS, and significantly different means were separated by the least significant difference (LSD) $t$ test $(P=0.05)$ (SAS System for Mixed Models, SAS Institute Inc.).

\section{RESULTS}

Pythium species isolated from turfgrass roots. There were 109 samples visually inspected for the presence of oospores in roots from putting greens of 39 golf courses in Maryland, Pennsylvania, Virginia, Delaware, New Jersey, and North Carolina from June 1995 to September 1997. Only 28 of 109 samples were selected for further study, and only 15 of these were diagnosed positive for Pythium-induced root dysfunction (Table 1). While the remaining 13 samples had low oospore populations, they were chosen for study based on symptoms of chlorosis or turf loss as noted by superintendents. Because roots with even high populations of oospores were generally white and healthy in appearance, no samples were diagnosed positive for Pythium root rot. Among the 28 isolates, there were 25 isolates from creeping bentgrass and 3 from annual bluegrass. Two isolates failed to produce sexual structures and could not be identified. Based on asexual and sexual characteristics, 8 different species were identified from the remaining 26 isolates. All eight species were found in creeping bentgrass. $P$. graminicola $(n=1)$ and P. torulosum $(n=2)$ were recovered from the three annual bluegrass samples. P. torulosum $(n=12)$ was the most frequently isolated species $(43 \%)$. All species identified closely fit the descriptions given by Middleton (11) and van der PlaatsNiterink (14). One isolate of $P$. graminicola (MD-P-5) and two isolates of P. torulosum (MD-P-11 and VA-P-1) died in storage after being identified. Therefore, these three and the two isolates of unknown species were not evaluated for pathogenicity.

Postemergence pathogenicity tests. Pathogenic isolates caused seedling wilt, chlorosis, and blight, and the inoculated isolates were reisolated from roots. At $18^{\circ} \mathrm{C}$, all isolates of $P$. aristosporum $(n=3)$, $P$. aphanidermatum $(n=1)$, and $P$. volutum $(n=1)$ caused severe blighting (Table 2). 
The pathogenicity levels of $P$. torulosum ( $n=$ $10)$ and $P$. vanterpoolii $(n=4)$ ranged from nonpathogenic to moderately aggressive. $P$. graminicola $(n=1)$ caused a low level of disease.

At $28^{\circ} \mathrm{C}$, only isolates of $P$. aristosporum $(n=3)$ and $P$. aphanidermatum $(n=1)$ were highly aggressive (Table 2 ). $P$. volutum and $P$. graminicola incited a moderate level of disease. All isolates of $P$. torulosum and $P$. vanterpoolii were either nonpathogenic or had a low level of aggressiveness. At both temperatures, $P$. ultimum $(n=1)$ caused a low level of disease and isolates of $P$. catenulatum $(n=2)$ were nonpathogenic.

Effect of temperature on aggressiveness. Except for $P$. volutum, there was no significant effect of incubation temperature on highly aggressive isolates (Table 2). All isolates of $P$. aristosporum $(n=3)$ and $P$. aphanidermatum $(n=1)$ were highly aggressive, regardless of temperature (18 or $\left.28^{\circ} \mathrm{C}\right)$. The isolate of $P$. volutum caused a high level of disease at $18^{\circ} \mathrm{C}$, but it was moderately aggressive ( $14 \%$ mortality) at $28^{\circ} \mathrm{C}$. The aggressiveness of $P$. graminicola was moderate (15\% mortality) at $28^{\circ} \mathrm{C}$ and low (7\% mortality) at $18^{\circ} \mathrm{C}$. Most isolates of $P$. torulosum, $P$. vanterpoolii, and $P$. catenulatum had either a low level of aggressiveness or were nonpathogenic at both temperatures. The isolate of $P$. ultimum had a low level of aggressiveness regardless of temperature.

With few exceptions, incubation temperature appeared to have little effect on the relative aggressiveness of the isolates (Table 2). Two isolates of $P$. torulosum (MD-P-21 and NC-P-1) were moderately aggressive at $18^{\circ} \mathrm{C}$, but had a low level of aggressiveness at $28^{\circ} \mathrm{C}$. P. vanterpoolii (DE-P-3) was moderately aggressive at $18^{\circ} \mathrm{C}$, but was nonpathogenic at $28^{\circ} \mathrm{C}$.

Pythium growth rate and level of aggressiveness. In general, isolates of $P$. aristosporum $(n=3)$ and $P$. aphaniderma-

Table 1. Source of Pythium species isolates, dates of isolation, approximate age of the putting green, and lab diagnosis for each sample

\begin{tabular}{|c|c|c|c|c|}
\hline Pythium species and isolate number & Source & $\begin{array}{c}\text { Date } \\
\text { isolated }\end{array}$ & $\begin{array}{c}\text { Age of } \\
\text { green } \\
\text { (years) }\end{array}$ & $\begin{array}{c}\text { Lab } \\
\text { diagnosis }^{\mathrm{v}}\end{array}$ \\
\hline \multicolumn{4}{|l|}{ P. aphanidermatum (Edson) Fitzp. } & - \\
\hline \multicolumn{5}{|l|}{ P. aristosporum Vanterpool } \\
\hline MD-P-13 & Timbers at Troy G.C., MD & $6 / 96$ & $<1$ & - \\
\hline MD-P-24 & Bulle Rock G.C., MD & $7 / 97$ & $<1$ & + \\
\hline VA-P-3 & Raspberry Falls G.C., VA & $6 / 96$ & $<1$ & + \\
\hline \multicolumn{5}{|l|}{ P. catenulatum Matthews } \\
\hline MD-P-17 & Chartwell C.C., MD & $10 / 96$ & $>3$ & + \\
\hline MD-P-20 & Fairway Hills, MD & $12 / 96$ & 2 & _- \\
\hline \multicolumn{5}{|l|}{ P. graminicola Subramanian } \\
\hline MD-P-5 & Easton Club, MD & $6 / 95$ & $<1$ & + \\
\hline MD-P-28w & Sparrows Point C.C., MD & $6 / 97$ & $>3$ & + \\
\hline \multicolumn{5}{|l|}{ P. torulosum Coker \& F. Patterson } \\
\hline MD-P-9 & River Run G. \& C.C., MD & $10 / 95$ & $>3$ & - \\
\hline MD-P-11 & TPC at Avenel, MD & $5 / 96$ & $>3$ & - \\
\hline PA-P-1 & Hartefeld National G.C., PA & $6 / 95$ & $<1$ & + \\
\hline VA-P-1 & Elizabeth Manor G. \& C.C., VA & $2 / 96$ & $>3$ & - \\
\hline NJ-P-1 & Pebble Creek, NJ & $6 / 96$ & $<1$ & + \\
\hline PA-P-2 & Merion G.C., PA & $11 / 96$ & $<1^{\mathrm{x}}$ & - \\
\hline PA-P-3 & Merion G.C., PA & $3 / 97$ & $<2^{x}$ & + \\
\hline PA-P-4 & Merion G.C., PA & $4 / 97$ & $<2^{x}$ & + \\
\hline MD-P-21w & Fountainhead C.C., MD & $3 / 97$ & $>3$ & - \\
\hline MD-P-23 & Bear Creek Club, MD & $5 / 97$ & $<1$ & - \\
\hline NC-P-1 & Benvenue C.C., NC & 3/97 & Unknown & _- \\
\hline \multirow{2}{*}{\multicolumn{5}{|c|}{ P. ultimum Trow var. ultimum }} \\
\hline & & & & \\
\hline MD-P-18 & Marlton G.C., MD & $11 / 96$ & $<1$ & + \\
\hline \multicolumn{5}{|c|}{ P. vanterpoolii V. Kouyeas \& H. Kouyeas } \\
\hline MD-P-15 & Hillendale G.C., MD & $6 / 96$ & $3^{y}$ & - \\
\hline MD-P-27 & Hillendale G.C., MD & $7 / 97$ & $>3 y$ & + \\
\hline DE-P-2 & Wilmington C.C., DE & $5 / 96$ & $<2^{\mathrm{z}}$ & _ \\
\hline DE-P-3 & Wilmington C.C., DE & 3/97 & $<3^{\mathrm{z}}$ & - \\
\hline \multicolumn{5}{|l|}{ P. volutum Vanterpool \& Truscott } \\
\hline DE-P-4 & The Salt Pond, DE & 3/97 & $<1$ & + \\
\hline \multicolumn{5}{|l|}{ Pythium species unknown } \\
\hline MD-P-6 & Bay Club, MD & $6 / 95$ & $<2$ & + \\
\hline MD-P-16 & Baltimore C.C., MD & $6 / 95$ & 2 & + \\
\hline
\end{tabular}

${ }^{v}$ Laboratory diagnosis for Pythium-induced root dysfunction was either positive (+) or negative (-). A positive diagnosis was based on $\geq 66 \%$ of the plants containing some oospores and $\geq 2$ of 12 plants with $>20$ oospores per root system.

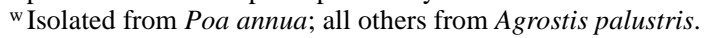

${ }^{\mathrm{x}}$ Fumigated and seeded in fall 1995.

y Fumigated and seeded in fall 1993.

${ }^{\mathrm{z}}$ Fumigated and seeded in fall 1994. tum $(n=1)$ grew rapidly, whereas $P$. torulosum $(n=10)$ and $P$. vanterpoolii $(n=4)$ were moderate or slow growing at 18 and $28^{\circ} \mathrm{C}$ (Table 2). The latter two species generally exhibited a low level of aggressiveness or were nonpathogenic. $P$. graminicola $(n=1)$ grew fast (42 $\mathrm{mm}$ per day) at $28^{\circ} \mathrm{C}$, but grew at a slow rate $(18 \mathrm{~mm}$ per day) at $18^{\circ} \mathrm{C}$. P. ultimum $(n=1)$ was a moderately fast-growing isolate at both temperatures, but had a low level of aggressiveness. The fastest growing species $(P$. aristosporum and $P$. aphanidermatum) were highly aggressive. Although $P$. volutum was a slow-growing species, it caused a high level of disease at $18^{\circ} \mathrm{C}$ and was moderately aggressive at $28^{\circ} \mathrm{C}$. Isolates of $P$. catenulatum $(n=2)$ grew moderately fast or rapidly, but none was pathogenic.

\section{DISCUSSION}

There were 28 Pythium isolates recovered from creeping bentgrass $(n=25)$ or annual bluegrass $(n=3)$ greens. Only about one-half of the isolates were from greens diagnosed as having Pythium-induced root dysfunction based on oospore populations in roots from plants with chlorotic leaves or leaves exhibiting tipdieback. The roots of diseased plants were sometimes discolored, but no rotting or root distortions were observed. A few infected roots occasionally had a pale yellow color or light-brown lesions. Sloughing of the root cortex was sometimes observed in samples that were judged both positive and negative for disease. Different levels of oospores were found among the 12 plants in all samples. Roots, however, generally appeared white and healthy, including roots with high populations of oospores. These observations were similar to those reported by Couch (3) and by Hodges and Coleman (7). Hodges and Coleman (7) described the infection of secondary roots of creeping bentgrass infected by $P$. aristosporum and $P$. arrhenomanes. They named the disease Pythium-induced root dysfunction because although plant growth was reduced, the pathogens failed to kill inoculated plants or produce root rot. In the pathogenicity tests described herein, no discoloration, lesions, or rotting were observed on roots of even severely wilted or blighted seedlings. Roots of some inoculated seedlings appeared shorter and may have had fewer root hairs than noninoculated seedlings. Oospores and occasionally sporangia were observed in roots of inoculated plants.

$P$. aristosporum $(n=3)$ was the most frequently isolated species shown to be highly aggressive at 18 and $28^{\circ} \mathrm{C}$. This species was reported to cause a severe rot of wheat (Triticum aestivum) at lower temperatures $\left(15\right.$ to $\left.18^{\circ} \mathrm{C}\right)$ in the Pacific Northwest $(2,10)$. Hodges and Coleman (7) were first to report that $P$. aristosporum infected secondary roots of creeping bentgrass. A generally high level of pathogenicity of this species to creeping bentgrass was re- 
ported in New York and North Carolina (1, 12). Hence, this and other research suggests that $P$. aristosporum may be among the more important causal agents of Pythium root rot or root dysfunction of creeping bentgrass grown on greens in the eastern United States.

P. torulosum was the most frequently (43\%) recovered species. According to van der Plaats-Niterink (14), P. torulosum was nonpathogenic to Agrostis, Lolium, and Festuca species. Similarly, Abad et al. (1) and Nelson and Craft (12) also reported that $P$. torulosum was their most frequently isolated species, which they found to be either nonpathogenic or weakly pathogenic to creeping bentgrass. Endo (4) also associated $P$. torulosum with Pythium root rot in California. Although most P. torulosum isolates were nonpathogenic or had a low level of aggressiveness, two isolates were moderately aggressive. Hsiang et al. (8) also reported that some $P$. torulosum isolates caused moderate damage to creeping bentgrass and perennial ryegrass at both low $\left(13^{\circ} \mathrm{C}\right)$ and high temperatures $\left(30^{\circ} \mathrm{C}\right)$ in lab and greenhouse studies. These reports suggest that some isolates of $P$. torulosum may cause root dysfunction in creeping bentgrass. During our investigation, $P$. torulosum was isolated five times from roots of samples diagnosed as being positive for Pythium-induced root dysfunction. It is, therefore, conceivable that the presence of high numbers of oospores of even nonpathogenic species may cause bentgrass roots to dysfunction. The mechanism of injury is the inability of roots to absorb adequate amounts of water and nutrients, perhaps by physically disrupting normal root function (3).

Except for $P$. volutum $(n=1)$, the influence of temperature on aggressiveness of the eight Pythium species was similar to that previously reported $(1,8,12)$. Hendrix and Campbell (5) believed $P$. volutum generally caused more damage at high temperatures; however, they stated that there were exceptions to this generalization among host species. Abad et al. (1) was first to report that $P$. volutum $(n=2)$ caused root and crown rot in creeping bentgrass and found this species to be moderately to highly aggressive. Test results showed that $P$. volutum caused $100 \%$ damping-off at $18^{\circ} \mathrm{C}$ and $14 \%$ damping-off at $28^{\circ} \mathrm{C}$, confirming the findings of Abad et al. (1).

There are no known reports regarding the relationship between growth rate and pathogenicity of Pythium species among turfgrass hosts. Our results indicated that rapid-growing species were highly aggressive, whereas slow-growing species were at best moderately aggressive. The one isolate of $P$. volutum was an exception. That isolate caused severe disease at $18^{\circ} \mathrm{C}$ and was moderately aggressive at $28^{\circ} \mathrm{C}$. $P$. volutum was one of slowest growing isolates evaluated, and the rates observed here were similar to the growth rate reported by Middleton (11).

Nelson and Craft (12) reported that nearly all cool-season turfgrasses are affected by Pythium root and crown rot during prolonged periods of wetness, regardless of temperature, in the northeastern United States. In this study, most (77\%) positive lab diagnoses for Pythium-induced root dysfunction in creeping bentgrass $(n=$ 13) were made from samples collected during relatively cool periods from March to June $(n=9)$ and November $(n=1)$ from greens less than 3 years of age. Both positive diagnoses in annual bluegrass were made in June from older greens. Of the 28 samples chosen for further study, only 3 were sent to the lab by superintendents between July and September. Our studies also showed that all isolates generally grew faster on CMA at the higher temperature, but most positive diagnoses were associated with cooler conditions. Hence, it appears that the naturally wetter soil conditions of spring and fall may be more important than temperature in the growth and production of infecting propagules by pathogens inciting Pythium-induced root dysfunction. In Iowa, however, the disease occurred during hot weather and in greens recently renovated using high sand mixes (7). Only two of our positive diagnoses in creeping bentgrass were made during the summer (July).

There were 15 isolates obtained from positive samples, and 8 were shown to be pathogenic to seedlings and had levels of aggressiveness ranging from low to high. There were 13 isolates from samples that were judged negative for Pythium-induced root dysfunction, based on low oospore populations in roots. Five of these isolates were pathogenic to seedlings with levels of

Table 2. Pathogenicity of Pythium species isolates to 'Crenshaw' creeping bentgrass seedlings and relative aggressiveness and growth rates of the isolates at 18 and $28^{\circ} \mathrm{C}$

\begin{tabular}{|c|c|c|c|c|c|c|}
\hline \multirow{2}{*}{$\begin{array}{l}\text { Pythium species } \\
\text { and isolate number }\end{array}$} & \multicolumn{2}{|c|}{ Seedling mortality $(\%)$} & \multirow{2}{*}{ Aggressiveness $^{v}$} & \multicolumn{2}{|c|}{ Growth rate $(\mathrm{mm} / 24 \mathrm{~h})$} & \multirow{2}{*}{$\begin{array}{c}\text { Lab } \\
\text { diagnosis }\end{array}$} \\
\hline & $18^{\circ} \mathrm{C}$ & $28^{\circ} \mathrm{C}$ & & $18^{\circ} \mathrm{C}$ & $28^{\circ} \mathrm{C}$ & \\
\hline \multicolumn{7}{|l|}{ Rapid growth } \\
\hline \multicolumn{7}{|l|}{ P. aristosporum } \\
\hline MD-P-13 & 100 & 92 & $\mathrm{H}$ & $26 \mathrm{a}^{\mathrm{y}}$ & $55 \mathrm{a}$ & - \\
\hline MD-P-24 & 94 & 97 & $\mathrm{H}$ & $25 \mathrm{a}$ & $48 \mathrm{~b}$ & + \\
\hline VA-P-3 & 100 & 96 & $\mathrm{H}$ & $24 \mathrm{ab}$ & $49 \mathrm{~b}$ & + \\
\hline \multicolumn{7}{|l|}{ P. aphanidermatum } \\
\hline MD-P-29 & 93 & 100 & $\mathrm{H}$ & $23 \mathrm{bc}$ & $39 \mathrm{~d}$ & - \\
\hline \multicolumn{7}{|l|}{ P. catenulatum } \\
\hline MD-P-17 & 0 & 0 & $\mathrm{~N}$ & $23 \mathrm{bcd}$ & $37 \mathrm{e}$ & + \\
\hline \multicolumn{7}{|l|}{ Moderate growth } \\
\hline \multicolumn{7}{|l|}{ P. torulosum } \\
\hline NJ-P-1 & 0 & 0 & $\mathrm{~N}$ & 22 cde & $32 \mathrm{f}$ & + \\
\hline NC-P-1 & $13^{x}$ & 1 & L-M & $22 \mathrm{c}-\mathrm{f}$ & $29 \mathrm{hi}$ & - \\
\hline PA-P-1 & 0 & 1 & $\mathrm{~N}-\mathrm{L}$ & $21 \mathrm{~d}-\mathrm{g}$ & $31 \mathrm{fgh}$ & + \\
\hline PA-P-2 & 0 & 0 & $\mathrm{~N}$ & $21 \mathrm{e}-\mathrm{h}$ & $32 \mathrm{f}$ & - \\
\hline MD-P-23 & 9 & 1 & $\mathrm{~L}$ & $21 e-j$ & $29 \mathrm{hi}$ & - \\
\hline MD-P-26 & 1 & 2 & $\mathrm{~L}$ & $21 \mathrm{ijk}$ & $27 \mathrm{kl}$ & + \\
\hline \multicolumn{7}{|l|}{ P. vanterpoolii } \\
\hline DE-P-2 & 0 & 0 & $\mathrm{~N}$ & $21 \mathrm{~d}-\mathrm{g}$ & 30 ghi & - \\
\hline MD-P-27 & 2 & 0 & $\mathrm{~N}-\mathrm{L}$ & $21 e-j$ & 30 ghi & + \\
\hline MD-P-15 & 0 & 0 & $\mathrm{~N}$ & $20 \mathrm{f}-\mathrm{k}$ & $29 \mathrm{hi}$ & - \\
\hline \multicolumn{7}{|l|}{ P. catenulatum } \\
\hline MD-P-20 & 0 & 0 & $\mathrm{~N}$ & $21 \mathrm{e}-\mathrm{i}$ & $35 \mathrm{e}$ & - \\
\hline \multicolumn{7}{|l|}{ P. ultimum } \\
\hline MD-P-18 & 1 & 2 & $\mathrm{~L}$ & 20 g-k & 30 ghi & + \\
\hline \multicolumn{7}{|l|}{ Slow growth } \\
\hline \multicolumn{7}{|l|}{ P. torulosum } \\
\hline MD-P-9 & 0 & 5 & N-L & 19 hij & $31 \mathrm{fgh}$ & - \\
\hline MD-P-21 & $16^{\mathrm{x}}$ & 1 & L-M & $19 \mathrm{ijk}$ & $20 \mathrm{f}-\mathrm{i}$ & - \\
\hline PA-P-4 & 9 & 1 & $\mathrm{~L}$ & $19 \mathrm{jk}$ & $31 \mathrm{fg}$ & + \\
\hline PA-P-3 & 7 & 2 & $\mathrm{~L}$ & $18 \mathrm{kl}$ & $29 \mathrm{hi}$ & + \\
\hline \multicolumn{7}{|l|}{ P. graminicola } \\
\hline MD-P-28 & 7 & 15 & L-M & $18 \mathrm{kl}$ & $42 \mathrm{c}$ & + \\
\hline \multicolumn{7}{|l|}{ P. volutum } \\
\hline DE-P-4 & $100^{x}$ & 14 & $\mathrm{M}-\mathrm{H}$ & $171^{z}$ & $18 \mathrm{k}$ & + \\
\hline \multicolumn{7}{|l|}{ P. vanterpoolii } \\
\hline DE-P-3 & $20^{\mathrm{x}}$ & 0 & N-M & $12 \mathrm{~m}$ & $23 \mathrm{j}$ & - \\
\hline
\end{tabular}

${ }^{\mathrm{v}}$ Range in aggressiveness in which $\mathrm{H}=$ highly aggressive, $\mathrm{M}=$ moderately aggressive, $\mathrm{L}=$ low level of aggressiveness, and $\mathrm{N}=$ not pathogenic.

${ }^{w}$ Laboratory diagnosis for disease was either positive (+) or negative (-).

${ }^{\mathrm{x}}$ Significant difference $(P=0.05)$ in seedling mortality due to temperature according to the $t$ test.

y Growth rate measurements followed by the same letter in the same column were not significantly different at $P=0.05$ according to the least significant difference $t$ test.

${ }^{\mathrm{z}}$ Growth rate at this temperature is not significantly $(P=0.05)$ different than that at the other temperature according to the least significant difference $t$ test. 
aggressiveness also ranging from low to high. Data and observations suggest, therefore, that although oospore populations in roots may be low, the potential for root disease still exists. Furthermore, infected roots were generally white and appeared healthy, unlike the discoloration or necrosis of roots associated with Pythium root rot $(1,12)$. Hence, a more reliable technique for diagnosing Pythium-induced root dysfunction is needed. Judging the diagnosis based on the perception by the superintendent that turf is discolored, thinning, unthrifty, or otherwise diseased and then assessing roots for oospores remains the most practical and expedient method currently available for diagnosing this disease. The fact that most isolates $(77 \%)$ were from creeping bentgrass samples collected during relatively cool and moist periods from generally young bentgrass greens ( $\leq 3$ years of seeding) is helpful information for the diagnostician. Hodges and Coleman (7) also noted that the disease was primarily a problem during a 1- to 2-year period fol- lowing reseeding of renovated greens and would normally cease to be a problem within 3 to 5 years.

\section{LITERATURE CITED}

1. Abad, Z. G., Shew, H. D., and Lucas, L. T. 1994. Characterization and pathogenicity of Pythium species isolated from turfgrass with symptoms of root and crown rot in North Carolina. Phytopathology 84:913-921.

2. Chamswarng, C., and Cook, R. J. 1985. Identification and comparative pathogenicity of Pythium species from wheat roots and wheatfield soils in the Pacific Northwest. Phytopathology 75:821-827.

3. Couch, H. B. 1995. Diseases of Turfgrasses. 3rd ed. Kreiger Publishing Co., Malabar, FL.

4. Endo, R. M. 1961. Turfgrass diseases in Southern California. Plant Dis. Rep. 45:869-873.

5. Hendrix, Jr., F. F., and Campbell, W. A. 1973. Pythiums as plant pathogens. Annu. Rev. Phytopathol. 11:77-98.

6. Hendrix, Jr., F. F., Campbell, W. A., and Moncrief, J. B. 1970. Pythium species associated with golf turfgrasses in the south and southeast. Plant Dis. Rep. 54:419-421.

7. Hodges, C. F., and Coleman, L. W. 1985. Pythium-induced root dysfunction of secon- dary roots of Agrostis palustris. Plant Dis. 69: 336-340.

8. Hsiang, T., Wu, C., Yang, L., and Liu, L. 1995. Pythium root rot associated with coolseason dieback of turfgrass in Ontario and Quebec. Can. Plant Dis. Surv. 75(2):191-195.

9. Kannwischer, M. E., and Mitchell, D. J. 1978. The influence of a fungicide on the epidemiology of black shank of tobacco. Phytopathology 68:1760-1765.

10. Lipps, P. E., and Bruehl, G. W. 1978. Snow rot of winter wheat in Washington. Phytopathology 68:1120-1127.

11. Middleton, J. T. 1943. The taxonomy, host range and geographic distribution of the genus Pythium. Mem. Torrey Bot. Club 20:1-171.

12. Nelson, E. B., and Craft, C. M. 1991. Identification and comparative pathogenicity of $P y$ thium spp. from roots and crowns of turfgrasses exhibiting symptoms of root rot. Phytopathology 81:1529-1536.

13. Steel, R. G. D., James, H. T., and Dickey, D. A. 1997. Principles and Procedures of Statistics: A Biometrical Approach. 3rd ed. The McGraw-Hill Companies, Inc., New York.

14. van der Plaats-Niterink, A. J. 1981. Monograph of the Genus Pythium. Studies in Mycology, Vol. 21. Centraalbureau voor Schimmelcultures, Baarn, the Netherlands. 